\title{
Long Noncoding RNAs and Human Osteosarcoma
}

\author{
Arshad Ali ${ }^{1,2,3}$, Lifang Hu ${ }^{1,2,3}$, Airong Qian ${ }^{1,2,3^{*}}$, Chu Chen ${ }^{4}$ and Tuanmin Yang ${ }^{4}$
}

${ }^{1}$ Laboratory for Bone Metabolism, Key Laboratory for Space Bioscience and Biotechnology, School of Life Sciences, Northwestern Polytechnical University, Xi'an, Shaanxi 710072, P. R. China

${ }^{2}$ Research Center for Special Medicine and Health Systems Engineering, School of Life Sciences, Northwestern Polytechnical University, Xi'an, Shaanxi 710072, China ${ }^{3}$ NPU-UAB Joint Laboratory for Bone Metabolism, School of Life Sciences, Northwestern Polytechnical University Xi'an, Shaanxi 710072, China

${ }^{4}$ Hong-Hui Hospital, Xi'an Jiaotong University College of Medicine, Xi'an, Shaanxi, China

\begin{abstract}
Osteosarcoma is the most commonly diagnosed malignancies in children and adolescents, pathologically characterized by spindle cells and deviant osteoid formation. Although significant evidences in therapeutic strategies have been accomplished, the conclusion is still unclear for the critical metastatic or persistent osteosarcoma. Therefore, it is essential to develop novel and effective biomarkers or therapeutic targets for diagnosis of osteosarcoma. Long noncoding RNAs (IncRNAs), as a novel class of noncoding RNA, are composed of transcripts longer than 200 nucleotides and play critical roles in development and progression of various cancers including osteosarcoma. LncRNAs are mainly involved in different biological process such cell growth, transcription, translation, epigenetic regulation, splicing, chromosome dosage compensation, imprinting, nuclear, cytoplasmic trafficking and cell cycle control. LncRNAs may act as oncogenic or tumor suppressive that can modulate osteosarcoma pathogenesis including cell growth, migration, proliferation, metastasis, invasion and cell apoptosis. In this review, we summarize the current knowledge of IncRNAs and its critical role in progression of osteosarcoma. It will be helpful for researchers to evaluate the functional role of IncRNAs in the development of osteosarcoma and enhance the efficacy of therapeutic treatment modalities.
\end{abstract}

Keywords: LncRNAs; Osteosarcoma; Progression; Metastasis; Mechanisms

\section{Introduction}

Osteosarcoma is the highly aggressive malignant bone tumor and the second leading cause of death in adult and children worldwide [1]. Osteosarcoma is characterized as tumor that produce osteoid matrix with multinucleated cells $[2,3]$. About $10 \%-25 \%$ of patients were associated with lung metastasis, temporarily pulmonary damage were the major causes of osteosarcoma mediated death [4]. Inclusive treatments such as chemotherapies and surgery resection have significantly improved the treatment strategy and survival rate of osteosarcoma patients [5]. Currently the 5-year survival rate of osteosarcoma patients has been enhanced to $70 \%$ [6,7]. However several osteosarcoma patients posses resistance to suitable chemotherapeutics and then die due to huge metastasis and tumor relapse, which is essential impediment for successful osteosarcoma treatments [8]. In spite of advance research to identify some novel therapeutic approaches, the overall diagnosis ratio of osteosarcoma patients has still reached a low level in past 30 years [9]. Based on biological characteristic of osteosarcoma, there exist a large scale of fuzzy regions that are involved in the exploration of molecular mechanisms associated with osteosarcoma metastasis, origination and chemo-resistance. Hence, suitable biomolecules that act as prognostic or diagnostic biomarkers and specific therapeutic targets are predictable to be identified and may intensely progress therapeutic efficacy as well as clinical outcomes for osteosarcoma patients. Inspiringly, several lncRNAs have recently been identified to play crucial role in osteosarcoma development.

Along coding genes, large numbers of lncRNAs transcripts exist in human genome. LncRNAs are transcribed in a precise manner during cell development, differentiation, cancer progression and other diseases [10-12]. Non coding RNAs (ncRNAs) are endogenously RNA molecules with no capability of coding protein. According to size of nucleotides, ncRNAs can be classified as small non coding RNAs (sncRNAs, $<200$ $\mathrm{nt}$ ) and $\operatorname{lncRNAs}(>200 \mathrm{nt}$ ) [13]. The small ncRNA such as microRNAs (miRNAs), transfer RNAs, small interfering RNAs (siRNAs), some ribosomal RNA and piwi-interacting RNAs, have been investigated to function in the tumorigenesis, metastasis and chemo-resistance. The wide spreading catalogue of lncRNAs is initially observed during the functional studies of human genome. LncRNAs are considered to have equivalent chromatin signatures to the coding genes. More and more recent researches have pointed out differences in the existence of specific histone letters [14-16] and splicing capability [15,17] among lncRNAs and coding genes, as well as with other lncRNAs according to chromatin structure $[13,18]$.

A large number of lncRNAs have been identified in various types of species as well as in tissues [19]. Some of lncRNAs are critical for organism development [20,21] and cancer progression [22]. LncRNAs are essential for certain biological processes such as transcription, translation, epigenetic regulation, splicing, chromosome dosage compensation, imprinting, nuclear and cytoplasmic trafficking and cell cycle control $[23,24]$. Advance research and investigation significantly disclose the roles of lncRNAs in the prognosis and pathogenesis of different human diseases such as osteoarthritis [25] and osteosarcoma [26]. Li et al. [26] reported the expression profile of lncRNAs in osteosarcoma and showed that approximately 25,733 lncRNAs consist of 789 downregulated and 403 upregulated lncRNAs. Further study showed that 32 pathways were downregulated transcripts and 34

*Corresponding author: Airong Qian, Laboratory for Bone Metabolism, Key Laboratory for Space Bioscience and Biotechnology, School of Life Sciences 127 West Youyi Road, Northwestern Polytechnical University, Xi'an, Shaanx 710072, P. R. China, Tel: 86-29-88491840; Fax: 86-29-88460332; E-mail: qianair@nwpu.edu.cn; drarshadhassan@yahoo.com

Received February 28, 2018; Accepted March 12, 2018; Published March 31 2018

Citation: Ali A, Hu L, Qian A,Chen C, Yang T (2018) Long Noncoding RNAs and Human Osteosarcoma. J Stem Cell Res Ther 8: 418. doi: 10.4172/2157 7633.1000418

Copyright: (c) 2018 Ali A, et al. This is an open-access article distributed unde the terms of the Creative Commons Attribution License, which permits unrestricted use, distribution, and reproduction in any medium, provided the original author and source are credited. 
pathways were upregulated transcripts. Recent studies implied that abnormal expressions of lncRNAs are directly involved in certain diseases including progression, invasion and metastasis of cancers $[27,28]$. In this review, based on characteristics and function of lncRNAs, we summarized the recent acquaintance among its pathological role in the pathogenesis of osteosarcoma. This article insights future research and helps the scientists to further elevate lncRNAs therapeutic roles in progression of osteosarcoma to develop noval diagnostics/prognostic biomarkers for treatment of osteosarcoma.

\section{Characteristics of lncRNAs}

Long non-coding RNAs (lncRNAs) are known as larger class of noncoding RNA constitutes as a size of $200 \mathrm{nt}-100 \mathrm{~kb}$ long transcripts without open-reading frame [29,30]. Its transcription processes are mostly occurred by RNA polymerase II and regulated by the transcriptional activators of the chromatin remodelers known as switching defective/sucrose non-fermenting (SWI/SNF). LncRNAs can be categorized into several broad groups such as sense lncRNAs, antisense lncRNAs, intronic lncRNAs, bidirectional lncRNAs, intergenic lncRNAs, untranslated region (UTR) associated lncRNAs and promoter-associated lncRNAs [10,31].

LncRNAs are mostly spliced, capped and polyadenylated in a same way as mRNA molecules [32]. LncRNAs are characterized as a large and highly heterogeneous set of ncRNAs. LncRNAs expression usually depend on both cellular and tissues context $[14,33]$. After discovery of H19 and XIST lncRNAs in 1990s [34,35], lncRNAs was considered as transcriptional noise with almost no or extremely slight functions [36]. LncRNAs can be existed in all cellular contexts especially with high proportion identified in the cytoplasm and nucleus [37]. The secondary structure of lncRNAs includes stem loops and hairpins, produced by posttranscriptional modifications, which allows their association with chromatin and other proteins as well as essential for lncRNAs' vast group of functions [38].

\section{Biological Function of IncRNAs}

The key function of lncRNAs has been ascribed to regulate the expression of coding genes by manipulating its adjacent genes (in cis) or modifying distinct genes on other chromosomes (in trans) [39]. At different levels of gene functions including transcription, translation, and protein function, lncRNAs can regulate individual genes or gene expression process by altering the basic transcription mechanism or through epigenetic mechanism. Unambiguously, the functions of lncRNAs are as follows: (1) LncRNAs located at the upstream promoter region can alter gene expression at downstream promoter area through chromatin remodeling and histone modification. (2) LncRNAs can regulate genes expression with the help of microRNA or siRNA and serve as a precursor for small RNA. (3) LncRNAs has closed association with special proteins and adjust protein activity (4) LncRNAs constitute various product due to alternative splicing [40].

Moreover, lncRNAs are associated with main cellular pathways regulating differentiation, proliferation and apoptosis that are concerned with pathogenesis of various human cancers [41,42]. During transcriptional or posttranscriptional stages, lncRNAs control various gene including oncogenes and tumor suppressor genes and also affect cellular processes such as cell proliferation, angiogenesis, apoptosis, migration, invasion and metastasis (Figure 1) [43-45].

\section{LncRNAs and Osteosarcoma}

\section{LncRNAs and osteosarcoma development and metastasis}

Osteosarcoma is lethal because of pulmonary metastasis with widespread progression that leads to respiratory failure. Tumor metastasis and invasion are multistep complex process in which tumor cells alter cell- extracellular matrix (ECM) associations at the primary tumor site to invade adjacent tissues and thus translocated through the vascular vessels to other systems to form secondary tumors [46]. Matrix metalloproteinases (MMPs) are family of proteolytic enzyme that plays an essential role in tumor metastasis and invasion by breaking the ECM and basement membrane. It has been investigated that during osteosarcoma cell migration and invasion, several lncRNAs promote or suppress cell proliferation, metastasis and invasion via modulating MMP-2 and MMP-9 secretion [47].

LncRNAs play essential roles in the osteosarcoma development, progression, prognosis, diagnosis and management [46]. LncRNAs can affect and modulate cellular processes such as cell cycle, differentiation, proliferation, and apoptosis [48]. Consequently, progression of cancer can be characterized by transcriptomics to distinguish among progression, metastasis and recurrence of human cancers including osteosarcoma. It has been investigated that metastasis-associated lung adenocarcinoma transcript 1 (MALAT1) / microRNA 376A (MIR376A) / transforming growth factor alpha (TGFA) play critical roles in the progression of osteosarcoma. MALAT1 initiated osteosarcoma development by suppressing MIR376A and promoting TGFA expression [49].

The HOX antisense intergenic RNA (HOTAIR), a well characterized lncRNA, which concerned in the progression and pathogenesis of different tumors. HOTAIR is most highly expressed in osteosarcoma and thus linked with advanced tumor stages, high histological grades, and poor survival. Therefore, HOTAIR may be a significant target in the diagnosis of human osteosarcoma [50]. Moreover, small nuclear RNA host gene 12 (SNHG12) induced cell proliferation and migration by overregulating angiomotin [5] gene expression in human osteosarcoma cells, which controls the expression of MMP-2/MMP-9 [51]. LncRNA (H19) may act as oncogenic or tumor suppressor in the progression of osteosarcoma. Recent evidences suggested that $H 19$ is concerned with the pathogenesis mechanisms of osteosarcoma and acts as an oncogenic lncRNA [52,53].

\section{LncRNA and Osteosarcoma Prognosis}

Interestingly, certain amount of oncogenic and tumor suppressive lncRNAs have been recognized in osteosarcoma pathogenesis, such as cell growth, apoptosis, proliferation, migration, invasion and metastasis. Here, we can recapitulate the possible roles and underline mechanisms of certain lncRNAs that are associated with osteosarcoma pathogenesis as shown in Table 1.

Overexpression of lncRNA Taurine Up-regulated Gene 1 (TUG1) in osteosarcoma initiated cell proliferation, inhibited cell apoptosis and arrest cell cycle at G0/G1 through underline function mechanisms with sponges miR-9-5p to downregulate the expression of $P O U$ domain class 2 transcription factor 1 (POU2F1). TUG1 has also close association with disease status. Therefore, TUG1 acts as a possible therapeutic target and as sovereign prognostic factor in osteosarcoma patients [54-56]. Increase expression of HOTTIP results to enhanced cell proliferation, invasion that associated with advance Enneking stage, metastasis and poor survival of osteosarcoma [57]. Upregulation of Fibroblast Growth Factor 3 antisense transcript 1 (FGFR3-AS1) in osteosarcoma 
Citation: Ali A, Hu L, Qian A,Chen C, Yang T (2018) Long Noncoding RNAs and Human Osteosarcoma. J Stem Cell Res Ther 8: 418. doi: 10.4172/21577633.1000418
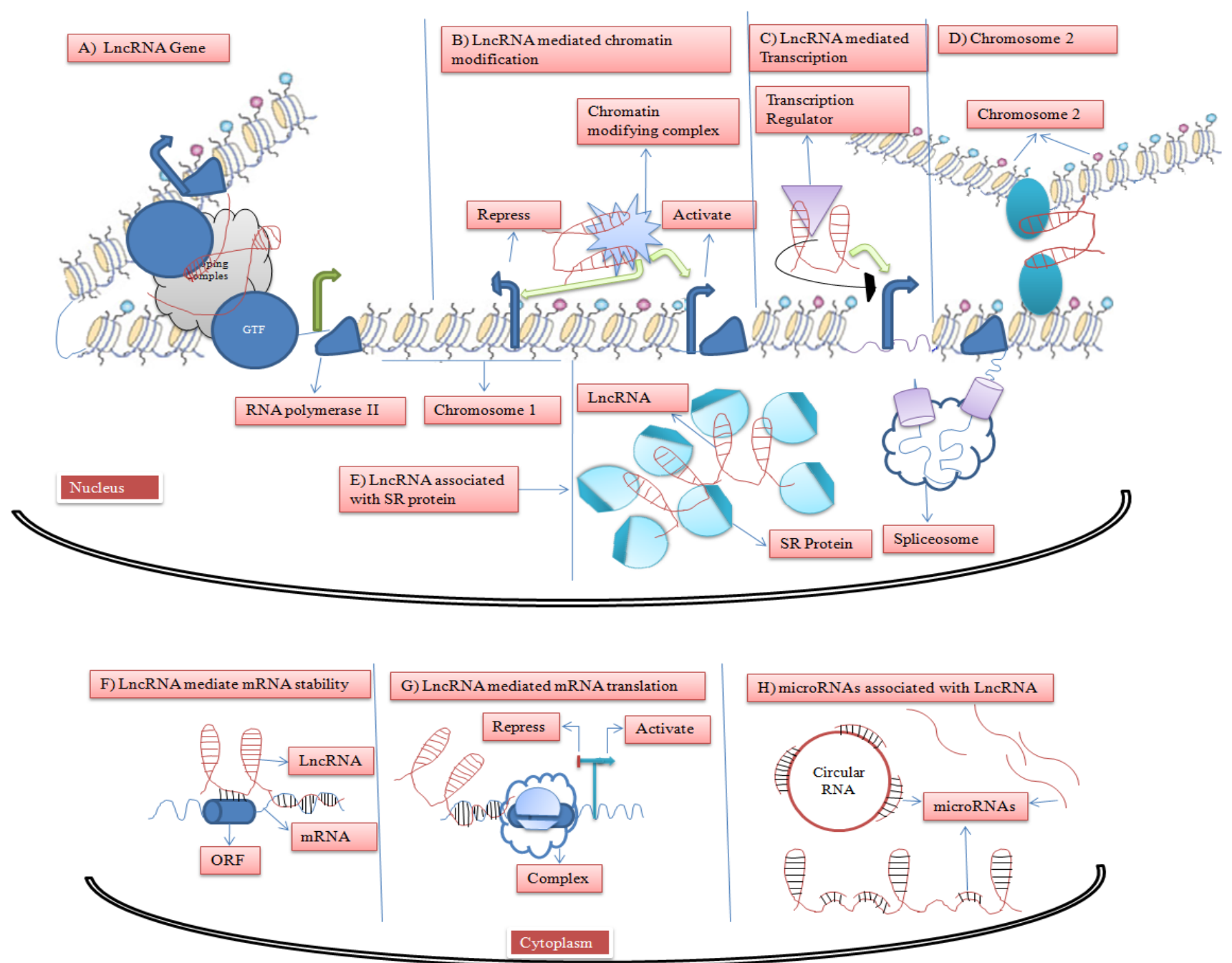

Figure 1: LncRNAs concerned with various cellular functions that act in different way such as to regulate gene expression and other different mechanism. (A) LncRNA gene associated complex (B) LncRNAs regulate gene expression at epigenetic level through binding chromatin modifying complexes to specifics genomics loci (C) LncRNAs modulate gene expression by changing the function of transcription factor and act as co activator or repressor (D) LncRNAs established interchromosomal linkage between two chromosomes (E) LncRNAs associated with splicing regulatory protein to regulate gene expression (F) LncRNAs closely linked with mRNA to increase mRNA stability and protect it from degradation (G) LncRNAs associated with mRNA to activate or repress its translation and regulate gene at posttranscriptional level $(H)$ LncRNAs compete with miRNAs and act as miRNAs sponges in the regulation of miRNAs level and gene expression.

is closely linked with increase tumor size, advance clinical stage and poor prognosis [58]. It has been investigated that aberrant expression of highly up-regulated in liver cancer $(H U L C)$ is directly related with clinical stages, distant metastasis and poor prognosis of osteosarcoma [59]. Overexpression of Breast Cancer Anti-Estrogen Resistance 4 (BCAR4) in osteosarcoma is connected with large tumor size, progressed enneking stage and unfavorable survival [60].

Distinctly upregulation of Zinc finger E-box binding homeobox 1 antisense 1 (ZEB1-AS1) in osteosarcoma has close association to tumor size, progressed clinical stage and poor prognosis via activating transcription of ZEB1 gene [61]. LncRNA maternally expressed gene 3 (MEG3) regulates p53 expression and is closely associated with osteosarcoma survival [62]. Similarly, upregulation of Forkhead box protein $C 2$ antisense 1 (FOXC2-AS1) is correlated with favorable survival for osteosarcoma patients [63]. LncRNA loc285194 is initially recognized in osteosarcoma but the underline functional mechanism remains unknown. Liu et al. [64] has reported that loc285194 may take a potential diagnostic role in various cancers such as colon cancer and osteosarcoma. Moreover, some additional lncRNAs have been recognized as autonomous prognostic biomarkers in osteosarcoma. Flockhart et al. [65] initially discovered BRAF-activated noncoding RNA (BANCR) in melanoma cells which is approximately 693bp in length. Overexpression of BANCR is significantly associated with large tumor size, distant metastasis, advanced clinical stage and poor prognosis of osteosarcoma [66]. Increased expression of urothelial carcinoma associated 1 (UCA1) has close association with positive distant metastasis, large tumor size and advanced clinical stage and acts as an autonomous prognostic indicator for poor survival of osteosarcoma [67].

Similarly, upregulation of antisense $H 19$ transcript (91H) has also significant correlations with large tumor size, progressed clinical stage and post-operative chemotherapy and acts as an autonomous prognosis 
Citation: Ali A, Hu L, Qian A,Chen C, Yang T (2018) Long Noncoding RNAs and Human Osteosarcoma. J Stem Cell Res Ther 8: 418. doi: 10.4172/21577633.1000418

Page 4 of 8

\begin{tabular}{|c|c|c|c|c|c|}
\hline Lncrnas & Size & $\begin{array}{l}\text { Genomic } \\
\text { Location }\end{array}$ & $\begin{array}{l}\text { Relative } \\
\text { Expression }\end{array}$ & Molecular Mechanism & Reference \\
\hline HULC & $500 \mathrm{bp}$ & $6 \mathrm{p} 24.3$ & Upregulated & $\begin{array}{l}\text { Inhibition of } H U L C \text { by a siRNA lead to reduces the proliferation, invasion and migration capacities of } \\
\text { OS. }\end{array}$ & {$[66,70,71]$} \\
\hline MALAT1 & $8.7 \mathrm{~kb}$ & $11 q 13.1$ & Upregulated & $\begin{array}{l}\text { Strong activation of wnt/beta-catenin signaling pathway through loss of PCDH10 tumor suppressor. } \\
\text { Promotes motility and invasion via MALAT1/miR-124/RBG2 signaling. Modulates P13K/AKT signaling. } \\
\text { Associated with Rho/ROCK Pathway }\end{array}$ & $\begin{array}{c}{[46,49,66} \\
69,72]\end{array}$ \\
\hline PACER & $793 \mathrm{bp}$ & 1q31.1 & Upregulated & promotes cell proliferation and migration by regulating COX-2 gene in a NFKB-dependent way & {$[66,73]$} \\
\hline$B A N C R$ & 693bp & 9q21.11-12 & Upregulated & $\begin{array}{l}\text { Associated with large tumor size, distant metastasis, and advanced clinical stage } \\
\text { an independent predictor of poor survival }\end{array}$ & {$[66,74]$} \\
\hline UCA1 & $2.3 \mathrm{~kb}$ & $19 \mathrm{p} 13.12$ & Upregulated & $\begin{array}{l}\text { Serve as a decoy by acting sponge and sink for miRNAs, which results in inducing carcinogenesis or } \\
\text { drug resistance. }\end{array}$ & {$[66,67]$} \\
\hline BCAR4 & $118 \mathrm{bp}$ & $16 \mathrm{p} 13.13$ & Upregulated & Increase proliferation and metastasis of osteosarcoma by activating GLI2-depended gene expression. & [60] \\
\hline HOTAIR1 & $2.2-\mathrm{kb}$ & $12 q 13.13$ & Upregulated & $\begin{array}{l}\text { Promotes cellular invasion and migration through upregulating the transcription of cyclin } E, B c l-2 \text {, } \\
\text { caspase- } 3 \text { and }-9 \text {, and matrix metalloproteinase (MMP) } 9 \text { and } 3 \text {. }\end{array}$ & {$[47,50,75]$} \\
\hline TUG1 & $7.5 \mathrm{~kb}$ & $22 q 12.2$ & Upregulated & $\begin{array}{l}\text { Promotes cell proliferation, migration, via associating with sponges' miR-9-5p to downregulates } \\
\text { POU2F1 expression. }\end{array}$ & {$[54,55,66]$} \\
\hline$H 19$ & $2.3 \mathrm{~kb}$ & $11 \mathrm{p} 15.5$ & Upregulated & $\begin{array}{l}\text { Induces osteosarcoma development via associated with miR-141. Also concern with Hedgehog } \\
\text { signaling pathway }\end{array}$ & {$[2,52]$} \\
\hline MFI2 & $951 \mathrm{bp}$ & $3 q 29$ & Upregulated & $\begin{array}{l}\text { Promotes cell proliferation and migration } \\
\text { by inducing expression of FOXP4 }\end{array}$ & [66] \\
\hline SNHG12 & $1.3 \mathrm{~kb}$ & $1 \mathrm{p} 35.3$ & Upregulated & Promotes cell proliferation and migration via increase expression of angiomotin gene & [51] \\
\hline $91 H$ & $120 \mathrm{~kb}$ & $11 \mathrm{p} 15.5$ & Upregulated & $\begin{array}{l}\text { Correlated with advanced clinical stage, chemotherapy after surgery, and tumor size }>5 \mathrm{~cm} \text {, an } \\
\text { independent prognostic factor for overall survival }\end{array}$ & {$[66,68]$} \\
\hline ODRUL & $319 \mathrm{bp}$ & $16 q 24.1$ & Upregulated & $\begin{array}{l}\text { Associated with doxorubicin resistance through induces expression of } A B C B 1 \text { (multidrug resistance } \\
\text { gene) }\end{array}$ & [66] \\
\hline HOTTIP & $4.6 \mathrm{~kb}$ & $7 \mathrm{p} 15.2$ & Upregulated & $\begin{array}{l}\text { Associated with WDR5/MLL complex to } \\
\text { activates Wnt/ß-catenin signaling pathway }\end{array}$ & {$[57,66]$} \\
\hline HNF1A-AS1 & $2.4 \mathrm{~kb}$ & $12 q 24.31$ & Upregulated & Modulate with cell proliferation and metastasis by regulating $\mathrm{Wnt} / \beta$-catenin signaling pathway & [66] \\
\hline FOXC2-AS1 & $319 \mathrm{bp}$ & $16 q 24.1$ & Upregulated & Associated with upregulation of $A B C B 1$, HIF1A and FOXC2 expression. & [63] \\
\hline ZEB1-AS1 & $2.6 \mathrm{~kb}$ & 10p11.22 & Upregulated & $\begin{array}{l}\text { Promote cell proliferation and metastasis though binding and selection of p300 to the ZEB1 promoter } \\
\text { region, that activates ZEB1 transcription }\end{array}$ & [61] \\
\hline LINCOO161 & $1 \mathrm{~kb}$ & $21 \mathrm{q} 21.3$ & Upregulated & $\begin{array}{l}\text { Promote cisplatin-induced apoptosis by interacting with sponges endogenous miR- } 645 \text { that regulates } \\
\text { IFIT2 expression }\end{array}$ & [66] \\
\hline loc285194 & $>2 \mathrm{~kb}$ & $3 q 13.31$ & Downregulated & Interact with miR-211 to regulates cell growth by activating p53 expression & [64] \\
\hline HIF2PUT & $2.8 \mathrm{~kb}$ & $2 p 21$ & Downregulated & Promote cell proliferation and migration by upregulating HIF-2 $\alpha$ expression & {$[66,75]$} \\
\hline TUSC7 & $>2 \mathrm{~kb}$ & $3 q 13.31$ & Downregulated & Promotes cell proliferation and increases colony formation in vitro & {$[66]$} \\
\hline MEG3 & $1.6 \mathrm{~kb}$ & $14 q 32.2$ & Downregulated & Positively regulates the expression of $p 53$ & [62] \\
\hline
\end{tabular}

Table 1: Different IncRNAs and the related regulation mechanism concerned with osteosarcoma

factor with poor outcomes of osteosarcoma patients [68]. Increased expression of MALAT1 correlated with distant metastasis, advance clinical stage and poor prognosis of osteosarcoma patients and acts as a self-determining predictive factor of patients' survival situation Table 1 [69].

\section{The Mechanism of Lncrnas Regulating Osteosarcoma Targeting mRNA}

Short- lived mRNA called $c$-myc or $c$-los mRNA, plays a critical role in maintaining normal function and its dysregulation will lead to oncogenesis [70-76]. Zhu et al. [63] documented three groups of doxorubicin-resistant MG-63/DXR cells and their paired parental MG-63 cells and recognized 3465 lncRNAs (1761 up regulated and 1704 downregulated) and 3278 mRNAs (1607 upregulated and 1671 downregulated) that were aberrantly transcribed in MG-63/DXR cells. The coexpression association among lncRNAs and mRNA was identified, such as NR-036444 and ENST00000563280 that cooperated with certain genes including $A B C B 1$ FOXC2 and HIF1A, and might have significant roles in doxorubicin resistance in osteosarcoma.
LncRNAs associated messenger RNAs (mRNAs) are usually less copious than normal protein-coding mRNAs but possessing stronger tissue and cell-specific lncRNAs expression platforms [50,51]. It has been studied that the SNHG12 enhances cell migration and proliferation via upregulating the expression of angiomotin [5] gene in human osteosarcoma cells. In addition, Ruan W et al. [51] identified that SNHG12 mRNA transcription was upregulated in osteosarcoma cell lines and tissues as compared with normal cell and tissues. Mammalian genomes encode several natural antisense RNAs that are complementary to their target sense RNAs. FGFR3 antisense transcript 1 (FGFR3- AS1) enhanced FGFR3 mRNA constancy and upregulated FGFR3 transcript through antisense associated with FGFR3 3'-UTR. Enhanced expression of FGFR3-AS1 is closely associated with large tumor size, advanced clinical stage, metastasis and poor outcomes of osteosarcoma. Hence lncRNA FGFR3-AS1 induced osteosarcoma growth via modifying its antisense transcript FGFR3 [58].

\section{Activating signal pathways}

Signaling Pathways as a molecular mechanism to play critical role in development of osteosarcoma has been elucidated as follow. 
Citation: Ali A, Hu L, Qian A,Chen C, Yang T (2018) Long Noncoding RNAs and Human Osteosarcoma. J Stem Cell Res Ther 8: 418. doi: 10.4172/21577633.1000418

Page 5 of 8

Chan et al. [2] investigated that aberrant Hh signaling in mature osteoblasts lead to pathogenesis of osteoblastic osteosarcoma. However, upregulation of $\mathrm{Hh}$ signaling promote Yap1 expression which is responsible for aberrant lncRNA H19 expression in malignant osteosarcoma. To date, limited studies investigated the basic roles of lncRNAs in osteosarcoma osteogenesis, development, metastasis, invasion, or chemotherapy resistance. It has been mentioned in a report that when lncRNAs were expressed differentially in osteosarcoma they were found to be involved in many of the pathways showing that IncRNAs can work as therapeutic targets in osteosarcoma [26]. When P50- associated COX-2 extragenic RNA (PACER) was overexpressed in osteosarcoma tissues and cell lines influenced the $C O X-2$ gene was activated in an NF- $\mathrm{kB}$-dependent manner and worked as an oncogene in osteosarcoma (Figure 2) [73].

\section{Acting as a miRNA sponge}

MicroRNAs (miRNAs) are new class of noncoding RNA of about 18-25 nucleotides in sizes. miRNAs can dysregulate gene expression through binding to the $3^{\prime}$-untranslational region (UTR) of their target mRNAs that lead to translation suppression and mRNA degradation [77]. Through negative intervention of their target genes, miRNAs play crucial role in several biological processes such as cell survival, differentiation, proliferation, apoptosis, metabolism, autophagy and motility $[78,79]$. Moreover, different oncogenes or tumor suppressor genes are also the targets of miRNAs and numerous miRNAs have been involved in tumorgenesis and malignant progression of various human cancers such as osteosarcoma [80,81]. LncRNAs can also regulate gene expression at posttranscriptional levels and can act as endogenous 'sponge' and under regulate a chain of microRNAs. Moreover, a lot of



Figure 2: Mechanism of IncRNAs in the pathogenesis of osteosarcoma. (A) TUG1 suppresses POU2F expression and associate with miRNAs to activated cell cycle and cell proliferation but suppress apoptosis. (B) MALAT1 activated signaling pathway and miRNAs mediate its function to control cell growth and proliferation. (C) Hedgehog signaling upregulates H19 along with miRNAs to promote cell proliferation and suppress apoptosis. (D) CTCF binding factors regulates PACER function via targeting COX-2 gene which activate cell proliferation, invasion, and metastasis.

\begin{tabular}{|c|c|c|c|}
\hline $\begin{array}{l}\text { Mechanism Of Gene } \\
\text { Regulation }\end{array}$ & $\begin{array}{l}\text { Responsible } \\
\text { Lncrnas }\end{array}$ & Targeted Site or Molecules & References \\
\hline \multirow{3}{*}{$\begin{array}{l}\text { Trancription Level } \\
\text { (targeting mRNA) }\end{array}$} & SNHG12 & Upregulate the expression of angiomotin (AMOT) gene. & [51] \\
\hline & FGFR3- AS1 & $\begin{array}{l}\text { Enhance FGFR3 mRNA constancy and upregulated FGFR3 transcript through antisense associated with FGFR3 } \\
\text { 3'-UTR. }\end{array}$ & [58] \\
\hline & PANDA & $\begin{array}{l}\text { Block apoptosis through association with the transcription factor NF-YA to decrease expression of pro-apoptotic } \\
\text { genes. }\end{array}$ & {$[23,88]$. } \\
\hline \multirow{4}{*}{$\begin{array}{l}\text { Posttranscription level } \\
\text { (As a miRNA sponge) }\end{array}$} & linc-MD1 & Interact with miR-133 and MiR-135 to regulate the expression of MAML1 and MEF2C. & [82] \\
\hline & HULC & Interact with miR-372 to downregulate its expression. & [71] \\
\hline & loc285194 & Posses' reciprocal repression between MiR-211 and loc285194. & [64] \\
\hline & MALAT1 & Interact with splicing factors (SR) proteins and enhances their distribution in nuclear speckle domains. & [86] \\
\hline \multirow{3}{*}{ Epigenetics level } & Xist, & silencing X-chromosome by interacting with the polycomb repressive complex 2 (PRC2) & [89] \\
\hline & HOTAIR & $\begin{array}{l}\text { Repress transcription in trans of } H O X D \text { genes. This repressive action is mediated by the interaction of HOTAIR } \\
\text { with } P R C 2 \text {. }\end{array}$ & [90] \\
\hline & PCAT-1 & $\begin{array}{l}\text { As a prostate-specific regulator of cell proliferation, target of } P R C 2 \text {, functioning as a transcriptional repressor in a } \\
\text { subset of various cancer }\end{array}$ & [91] \\
\hline
\end{tabular}

Table 2: Mechanisms of gene regulation and their responsible IncRNAs that target particular site or molecules. 
lncRNAs exist that can regulate gene at posttranscriptional levels are as follow (Table 2). Long intergenic non protein coding RNA-muscle differentiation 1 (linc-MD1) regulates the expression of transcription factors such as mastermind-like 1 (MAML1) and myocyte enhancer factor 2C (MEF2C) with the association of miR-133 and miR-135 [82].

HULC interacts with miR-372 and down regulate its expression [71]. HULC plays critical role in progression of human cancer including osteosarcoma [83-91], which may point out the critical reason that miR372 frequently downregulated in osteosarcoma patients. Loc285194 may possess reciprocal repression with miR-211 [64]. GAS5 may act as an endogenous sponge for miR-21 [84]. Hence, lncRNAs also cooperate with certain regulatory system including 'competitive endogenous RNA (CeRNA)' [85] where microRNA response elements may function as outcomes of a new process through which microRNA can modulates both protein coding and non coding genes including lncRNAs. LncRNAs can also serve as key regulator of alternative splicing and pre-mRNA process. For example, MALAT1 is capable to cooperate with splicing factors serine/arginine [16] proteins and manipulate their allocation in nuclear speckle domains [86]. Since both lncRNAs and miRNAs can act as tumor suppressor or oncogenes in osteosarcoma. The association among miRNAs and lncRNAs intimate the occurrence of competitive RNA regulatory system, which will further help to recognized the molecular mechanism that involved in pathogenesis of osteosarcoma [87].

\section{Conclusion and Future Perspective}

In this review, we summarized the feature of lncRNAs, biological function of lncRNAs and their pathological roles concerned with osteosarcoma. Different lncRNAs are closely associated with the pathogenesis and prognosis of osteosarcoma and act as potential diagnostic or prognostic biomarkers. Additionally, lncRNAs promote the development and progression of osteosarcoma via regulating cell growth, proliferation, metastasis, migration, invasion and cell apoptosis. LncRNAs possess various underline mechanisms such as targeting the host related genes, challenging endogenous RNA, association of signaling pathway and so on. Moreover, some lncRNAs act as self governing prognostic predictor and some are concerned in competing to recently existed chemotherapeutics like cisplatin and doxorubicin. Therefore, these result clarified that lncRNAs act as a potential therapeutic target for treatment of osteosarcoma.

LncRNAs has been spotlighted for powerful research, and a broad range of functional roles have already been attributed in the progression of osteosarcoma. However, the absolute abundance and variety of lncRNAs pose a challenge for their classification and role in the regulation of cell cycle, growth, proliferation, metastasis, invasion and prognosis of osteosarcoma. A greater understanding of lncRNAsto-cell signaling relationship - that is, how and which lncRNAs dictate a cell signaling pathway will be required to initiate osteosarcoma progression. What is the comprehensive mechanism of lncRNAs with the progression and pathogenesis of osteosarcoma? How can lncRNAs regulate the initiation and progression of osteosarcoma? What is the relationship of cell cycle regulatory genes with lncRNAs? What is the exact structure of lncRNAs that interact with specific target proteins to enhance life span of lncRNAs? This could ultimately permit the functional assignation and validation of lncRNAs and might be hugely informative in the hypothesis of lncRNA in the development of osteosarcoma. Given such giant potential, lncRNAs has begun to produce substantial interest in the development and progression of osteosarcoma.

\section{Acknowledgements}

This work was supported by the National Natural Science Foundation of China (grant numbers 31570940, 31400725, 81772017), the Shenzhen Science and Technology Project (grant number JCYJ20160229174320053), the Project Funded by China Postdoctoral Science Foundation (grant number 2017M610653 2015T81051), Young Talent Fund of University Association for Science and Technology in Shaanxi, China (grant number 20170401) and the Fundamental Research Funds for the Central Universities (grant number 3102016ZY037)

\section{References}

1. Ottaviani G, Jaffe N (2009) The epidemiology of osteosarcoma. Cancer Treat Res 152: 3-13. [PubMed]

2. Chan LH, Wang W, Yeung W, Deng Y, Yuan P, et al. (2014) Hedgehog signaling induces osteosarcoma development through Yap1 and H19 overexpression. Oncogene 33: 4857-4866.[PubMed]

3. Sathiyamoorthy S, Ali SZ (2012) Osteoblastic osteosarcoma: cytomorphologic characteristics and differential diagnosis on fine-needle aspiration. Acta Cyto 56: 481-486. [PubMed]

4. Miller BJ, Cram P, Lynch CF, Buckwalter JA (2013) Risk factors for metastatic disease at presentation with osteosarcoma: an analysis of the SEER database. J Bone Joint Surg Am 95: e89. [PubMed]

5. Iwamoto Y, Tanaka K, Isu K, Kawai A, Tatezaki S, et al. (2009) Multiinstitutional phase II study of neoadjuvant chemotherapy for osteosarcoma (NECO study) in Japan: NECO-93J and NECO-95J. J Orthop Sci 14: 397-404. [PubMed]

6. Allison DC, Carney SC, Ahlmann ER, Hendifar A, Chawla S, et al. (2012) A meta-analysis of osteosarcoma outcomes in the modern medical era. Sarcoma : 704872.

7. Jaffe N (2009) Osteosarcoma: review of the past, impact on the future. The American experience. Cancer Treat Res 152: 239-262.

8. Bennett JH, Thomas G, Evans AW, Speight PM (2000) Osteosarcoma of the jaws: a 30-year retrospective review. Oral Surg Oral Med Oral Pathol Oral Radiol Endod 90: 323-332. [PubMed]

9. Xu H, Niu X, Zhang Q, Hao L, Ding Y, et al. (2011) Synergistic antitumor efficacy by combining adriamycin with recombinant human endostatin in an osteosarcoma model. Oncol Lett 2: 773-778. [PubMed]

10. Ponting CP, Oliver PL, Reik W (2009) Evolution and functions of long noncoding RNAs. Cell 136: 629-641. [PubMed]

11. Nam JW, Bartel DP (2012) Long noncoding RNAs in C. elegans. Genome Res 22: 2529-2540.[PubMed]

12. Sebe-Pedros A, Ballare C, Parra-Acero H, Chiva C, Tena JJ, et al. (2016) The Dynamic Regulatory Genome of Capsaspora and the Origin of Animal Multicellularity. Cell 165: 1224-1237. [PubMed]

13. Sundaram GM, Veera Bramhachari P (2017) Molecular interplay of proinflammatory transcription factors and non-coding RNAs in esophageal squamous cell carcinoma. Tumour Biol 39: 1010428317705760. [PubMed]

14. Alam T, Medvedeva YA, Jia H, Brown JB, Lipovich L, et al. (2014) Promoter analysis reveals globally differential regulation of human long non-coding RNA and protein-coding genes. PLoS One 9): e109443. [PubMed]

15. Mele M, Mattioli K, Mallard W, Shechner DM, Gerhardinger C, et al. (2017) Chromatin environment, transcriptional regulation, and splicing distinguish lincRNAs and mRNAs. Genome Res 27: 27-37. [PubMed]

16. Birney E, Stamatoyannopoulos JA, Dutta A, Guigo R, Gingeras TR, et al. (2007) Identification and analysis of functional elements in $1 \%$ of the human genome by the ENCODE pilot project. Nature 447: 799-816. [PubMed]

17. Schlackow M, Nojima T, Gomes T, Dhir A, Carmo-Fonseca M, et al. (2017) Distinctive Patterns of Transcription and RNA Processing for Human lincRNAs. Mol Cell 65: 25-38. [PubMed]

18. Marques AC, Hughes J, Graham B, Kowalczyk MS, Higgs DR, et al. (2013) Chromatin signatures at transcriptional start sites separate two equally populated yet distinct classes of intergenic long noncoding RNAs. Genome Biol 14: R131. [PubMed]

19. Mele M, Rinn JL (2016) Cat's Cradling the 3D Genome by the Act of LncRNA Transcription. Mol Cell 62: 657-664. [PubMed]

20. Ulitsky I, Shkumatava A, Jan CH, Sive H, Bartel DP (2011) Conserved function 
of lincRNAs in vertebrate embryonic development despite rapid sequence evolution. Cell 147: 1537-1550. [PubMed]

21. Sauvageau M, Goff LA, Lodato S, Bonev B, Groff AF, et al. (2013) Multiple knockout mouse models reveal lincRNAs are required for life and brain development. Elife 2: e01749. [PubMed]

22. Arun G, Diermeier S, Akerman M, Chang KC, Wilkinson JE, et al. (2016) Differentiation of mammary tumors and reduction in metastasis upon Malat1 IncRNA loss. Genes Dev 30: 34-51.

23. Hung T, Wang Y, Lin MF, Koegel AK, Kotake Y, et al. (2011) Extensive and coordinated transcription of noncoding RNAs within cell-cycle promoters. Na Genet 43: 621-629. [PubMed]

24. Guo F, Guo L, Li Y, Zhou Q, Li Z (2015) MALAT1 is an oncogenic long noncoding RNA associated with tumor invasion in non-small cell lung cance regulated by DNA methylation. Int J Clin Exp Pathol 8): 15903-15910. [PubMed]

25. Xing D, Liang JQ, Li Y, Lu J, Jia HB, et al. (2014) Identification of long noncoding RNA associated with osteoarthritis in humans. Orthop Surg 6: 288293. [PubMed]

26. Li JP, Liu LH, Li J, Chen Y, Jiang XW, et al. (2013) Microarray expression profile of long noncoding RNAs in human osteosarcoma. Biochem Biophys Res Commun 433: 200-206.

27. Xia H, Chen Q, Chen Y, Ge X, Leng W, et al. (2016) The IncRNA MALAT1 is a novel biomarker for gastric cancer metastasis. Oncotarget 7: 56209-56218. [PubMed]

28. Deng H, Wang JM, Li M, Tang R, Tang K, et al. (2017) Long non-coding RNAs: New biomarkers for prognosis and diagnosis of colon cancer. Tumour Biol 39: 1010428317706332. [PubMed]

29. Mattick JS (2001) Non-coding RNAs: the architects of eukaryotic complexity EMBO Rep 2: 986-991. [PubMed]

30. Lee C, Kikyo N (2012) Strategies to identify long noncoding RNAs involved in gene regulation. Cell Biosci 2: 37. [PubMed]

31. Derrien T, Johnson R, Bussotti G, Tanzer A, Djebali S, et al. (2012) The GENCODE $v 7$ catalog of human long noncoding RNAs: analysis of their gene structure, evolution, and expression. Genome Res 22: 1775-1789. [PubMed]

32. Quinn JJ, Chang HY (2016) Unique features of long non-coding RNA biogenesis and function. Nat Rev Genet 17: 47-62. [PubMed]

33. Harrow J, Frankish A, Gonzalez JM, Tapanari E, Diekhans M, et al. (2012) GENCODE: the reference human genome annotation for The ENCODE Project. Genome Res 22: 1760-1774. [PubMed]

34. Brannan Cl, Dees EC, Ingram RS, Tilghman SM (1990) The product of the H19 gene may function as an RNA. Mol Cell Biol 10: 28-36. [PubMed]

35. Brockdorff N, Ashworth A, Kay GF, McCabe VM, Norris DP, et al. (1992) The product of the mouse Xist gene is a $15 \mathrm{~kb}$ inactive X-specific transcrip containing no conserved ORF and located in the nucleus. Cell 71: 515-526. [PubMed]

36. van Bakel $H$, Hughes TR (2009) Establishing legitimacy and function in the new transcriptome. Brief Funct Genomic Proteomic 8: 424-436. [PubMed]

37. Bolha L, Ravnik-Glavac M, Glavac D (2017) Long Noncoding RNAs as Biomarkers in Cancer. Dis Markers 2017: 7243968. [PubMed]

38. Rinn JL, Chang HY (2012) Genome regulation by long noncoding RNAs. Annu Rev Biochem 81: 145-166. [PubMed]

39. Chen F, Li Y, Feng Y, He X, Wang L (2016) Evaluation of Antimetastatic Effect of IncRNA-ATB siRNA Delivered Using Ultrasound-Targeted Microbubble Destruction. DNA Cell Biol 35: 393-397. [PubMed]

40. Wilusz JE, Sunwoo H, Spector DL (2009) Long noncoding RNAs: functional surprises from the RNA world. Genes Dev 23: 1494-1504. [PubMed]

41. Martens-Uzunova ES, Bottcher R, Croce CM, Jenster G, Visakorpi T, et al (2014) Long noncoding RNA in prostate, bladder, and kidney cancer. Eur Urol 65: 1140-1151. [PubMed]

42. Ren S, Peng Z, Mao JH, Yu Y, Yin C, et al. (2012) RNA-seq analysis of prostate cancer in the Chinese population identifies recurrent gene fusions, cancerassociated long noncoding RNAs and aberrant alternative splicings. Cell Res 22: 806-821. [PubMed]
43. Zhang H, Chen Z, Wang X, Huang Z, He Z, et al. (2013) Long non-coding RNA: a new player in cancer. J Hematol Oncol 6: 37. [PubMed]

44. Qiu MT, Hu JW, Yin R, Xu L (2013) Long noncoding RNA: an emerging paradigm of cancer research. Tumour Biol 34: 613-620. [PubMed]

45. Ji Q, Liu X, Fu X, Zhang L, Sui H, et al. (2013) Resveratrol inhibits invasion and metastasis of colorectal cancer cells via MALAT1 mediated Wnt/beta-catenin signal pathway. PLoS One 811: e78700. [PubMed]

46. Yang Z, Li X, Yang Y, He Z, Qu X, et al. (2016) Long noncoding RNAs in the progression, metastasis, and prognosis of osteosarcoma. Cell Death Dis 7 : e2389.

47. Li H, Zhang K, Liu LH, Ouyang Y, Bu J, et al. (2014) A systematic review of matrix metalloproteinase 9 as a biomarker of survival in patients with osteosarcoma. Tumour Biol 35: 5487-5491.

48. Huarte M, Guttman M, Feldser D, Garber M, Koziol MJ, et al. (2010) A large intergenic noncoding RNA induced by $\mathrm{p} 53$ mediates global gene repression in the p53 response. Cell 142: 409-419. [PubMed]

49. Luo W, He H, Xiao W, Liu Q, Deng Z, et al. (2016) MALAT1 promotes osteosarcoma development by targeting TGFA via MIR376A. Oncotarget 7 : 54733-54743. [PubMed]

50. Wang B, Su Y, Yang Q, Lv D, Zhang W, et al. (2015) Overexpression of Long Non-Coding RNA HOTAIR Promotes Tumor Growth and Metastasis in Human Osteosarcoma. Mol Cells 38: 432-440.

51. Ruan W, Wang P, Feng S, Xue Y, Li Y (2016) Long non-coding RNA small nucleolar RNA host gene 12 (SNHG12) promotes cell proliferation and migration by upregulating angiomotin gene expression in human osteosarcoma cells. Tumour Biol 37: 4065-4073.

52. Luo M, Li Z, Wang W, Zeng Y, Liu Z, et al. (2013) Long non-coding RNA H19 increases bladder cancer metastasis by associating with EZH2 and inhibiting E-cadherin expression. Cancer Lett 333: 213-221. [PubMed]

53. Ratajczak MZ, Shin DM, Schneider G, Ratajczak J, Kucia M (2013) Parenta imprinting regulates insulin-like growth factor signaling: a Rosetta Stone for understanding the biology of pluripotent stem cells, aging and cancerogenesis. Leukemia 27: 773-779. [PubMed]

54. Li Z, Shen J, Chan MT, Wu WK (2016) TUG1: a pivotal oncogenic long noncoding RNA of human cancers. Cell Prolif 49: 471-475.

55. Xie CH, Cao YM, Huang Y, Shi QW, Guo JH, et al. (2016) Long non-coding RNA TUG1 contributes to tumorigenesis of human osteosarcoma by sponging miR-9-5p and regulating POU2F1 expression. Tumour Biol 37: 15031-15041. [PubMed]

56. Ma B, Li M, Zhang L, Huang M, Lei JB, et al. (2016) Upregulation of long non-coding RNA TUG1 correlates with poor prognosis and disease status in osteosarcoma. Tumour Biol 37: 4445-4455.

57. Li F, Cao L, Hang D, Wang F, Wang Q (2015) Long non-coding RNA HOTTIP is up-regulated and associated with poor prognosis in patients with osteosarcoma Int J Clin Exp Pathol 8: 11414-11420.

58. Sun J, Wang X, Fu C, Zou J, Hua H, et al. (2016) Long noncoding RNA FGFR3AS1 promotes osteosarcoma growth through regulating its natural antisense transcript FGFR3. Mol Biol Rep 43: 427-436. [PubMed]

59. Uzan VR, Lengert A, Boldrini E, Penna V, Scapulatempo-Neto C, et al. (2016) High Expression of HULC Is Associated with Poor Prognosis in Osteosarcoma Patients. PLoS One 11: e0156774. [PubMed]

60. Chen F, Mo J, Zhang L (2016) Long noncoding RNA BCAR4 promotes osteosarcoma progression through activating GLI2-dependent gene transcription. Tumour Biol 37: 13403-13412.

61. Liu C, Lin J (2016) Long noncoding RNA ZEB1-AS1 acts as an oncogene in osteosarcoma by epigenetically activating ZEB1. Am J Transl Res 8: 40954105. [PubMed]

62. Tian ZZ, Guo XJ, Zhao YM, Fang Y (2015) Decreased expression of long non-coding RNA MEG3 acts as a potential predictor biomarker in progression and poor prognosis of osteosarcoma. Int J Clin Exp Pathol 8: 15138-15142. [PubMed]

63. Zhu KP, Zhang CL, Shen GQ, Zhu ZS (2015) Long noncoding RNA expression profiles of the doxorubicin-resistant human osteosarcoma cell line MG63/DXR 
Citation: Ali A, Hu L, Qian A,Chen C, Yang T (2018) Long Noncoding RNAs and Human Osteosarcoma. J Stem Cell Res Ther 8: 418. doi: 10.4172/21577633.1000418

Page 8 of 8

and its parental cell line MG63 as ascertained by microarray analysis. Int J Clin Exp Pathol 8: 8754-8773. [PubMed]

64. Liu Q, Huang J, Zhou N, Zhang Z, Zhang A, et al. (2013) LncRNA loc285194 is a p53-regulated tumor suppressor. Nucleic Acids Res 41: 4976-4987.

65. Flockhart RJ, Webster DE, Qu K, Mascarenhas N, Kovalski J, et al. (2012) BRAFV600E remodels the melanocyte transcriptome and induces BANCR to regulate melanoma cell migration. Genome Res 22: 1006-1014.

66. Chen R, Wang G, Zheng Y, Hua Y, Cai Z (2017) Long non-coding RNAs in osteosarcoma. Oncotarget 8: 20462-20475. [PubMed]

67. Li W, Xie P, Ruan WH (2016) Overexpression of IncRNA UCA1 promotes osteosarcoma progression and correlates with poor prognosis. J Bone Oncol 5: 80-85. [PubMed]

68. Xia WK, Lin QF, Shen D, Liu ZL, Su J, et al. (2016) Clinical implication of long noncoding RNA $91 \mathrm{H}$ expression profile in osteosarcoma patients. Onco Targets Ther 9: 4645-4652. [PubMed]

69. Gao KT, Lian D (2016) Long non-coding RNA MALAT1 is an independent prognostic factor of osteosarcoma. Eur Rev Med Pharmacol Sci 20: 3561-3565.

70. Sun XH, Yang LB, Geng XL, Wang R, Zhang ZC (2015) Increased expression of IncRNA HULC indicates a poor prognosis and promotes cell metastasis in osteosarcoma. Int J Clin Exp Pathol 8: 2994-3000. [PubMed]

71. Wang J, Liu X, Wu H, Ni P, Gu Z, et al. (2010) CREB up-regulates long noncoding RNA, HULC expression through interaction with microRNA-372 in live cancer. Nucleic Acids Res 38: 5366-5383. [PubMed]

72. Dong Y, Liang G, Yuan B, Yang C, Gao R, et al. (2015) MALAT1 promotes the proliferation and metastasis of osteosarcoma cells by activating the PI3K/Akt pathway. Tumour Biol 36: 1477-1486. [PubMed]

73. Qian M, Yang X, Li Z, Jiang C, Song D, et al. (2016) P50-associated COX2 extragenic RNA (PACER) overexpression promotes proliferation and metastasis of osteosarcoma cells by activating COX-2 gene. Tumour Biol 37 3879-3886. [PubMed]

74. Peng ZQ, Lu RB, Xiao DM, Xiao ZM (2016) Increased expression of the IncRNA BANCR and its prognostic significance in human osteosarcoma. Genet Mol Res: 15. [PubMed]

75. Wang Y, Yao J, Meng H, Yu Z, Wang Z, et al. (2015) A novel long non-coding RNA, hypoxia-inducible factor-2alpha promoter upstream transcript, function as an inhibitor of osteosarcoma stem cells in vitro. Mol Med Rep 11: 2534-2540. [PubMed]

76. Schiavi SC, Belasco JG, Greenberg ME (1992) Regulation of proto-oncogene mRNA stability. Biochim Biophys Acta 1114: 95-106.
77. Croce CM, Calin GA (2005) miRNAs, cancer, and stem cell division. Cell, 122 6-7. [PubMed]

78. John B, Enright AJ, Aravin A, Tuschl T, Sander C, et al. (2004) Human MicroRNA targets. PLoS Biol 2: e363. [PubMed]

79. Liu X, Fortin K, Mourelatos Z (2008) MicroRNAs: biogenesis and molecular functions. Brain Pathol 18: 113-121.

80. Nana-Sinkam SP, Croce CM (2013) Clinical applications for microRNAs in cancer. Clin Pharmacol Ther 93: 98-104. [PubMed]

81. Zhang C, Long F, Wan J, Hu Y, He H (2016) MicroRNA-205 acts as a tumor suppressor in osteosarcoma via targeting RUNX2. Oncol Rep 35: 3275-3284. [PubMed]

82. Cesana M, Cacchiarelli D, Legnini I, Santini T, Sthandier O, et al. (2011) A long noncoding RNA controls muscle differentiation by functioning as a competing endogenous RNA. Cell 147: 358-369. [PubMed]

83. Panzitt K, Tschernatsch MM, Guelly C, Moustafa T, Stradner M, et al. (2007) Characterization of HULC, a novel gene with striking up-regulation in hepatocellular carcinoma, as noncoding RNA. Gastroenterology 132: 330-342.

84. Zhang Z, Zhu Z, Watabe K, Zhang X, Bai C, et al. (2013) Negative regulation of IncRNA GAS5 by miR-21. Cell Death Differ : 1558-1568.

85. Salmena L, Poliseno L, Tay Y, Kats L, Pandolfi PP (2011) A ceRNA hypothesis: the Rosetta Stone of a hidden RNA language? Cell 146: 353-358. [PubMed]

86. Tripathi V, Ellis JD, Shen Z, Song DY, Pan Q, et al. (2010) The nuclear-retained noncoding RNA MALAT1 regulates alternative splicing by modulating SR splicing factor phosphorylation. Mol Cell 39: 925-938. [PubMed]

87. Jones KB, Salah Z, Del Mare S, Galasso M, Gaudio E, et al. (2012) miRNA signatures associate with pathogenesis and progression of osteosarcoma. Cancer Res 72: 1865-1877.

88. Hung T, Chang HY (2010) Long noncoding RNA in genome regulation prospects and mechanisms. RNA Biol 7: 582-585. [PubMed]

89. Zhao J, Sun BK, Erwin JA, Song JJ, Lee JT (2008) Polycomb proteins targeted by a short repeat RNA to the mouse X chromosome. Science 322: 750-756. [PubMed]

90. Zhang A, Xu M, Mo YY (2014) Role of the IncRNA-p53 regulatory network in cancer. J Mol Cell Biol 6: 181-191. [PubMed]

91. Prensner JR, lyer MK, Balbin OA, Dhanasekaran SM, Cao Q, et al. (2011) Transcriptome sequencing across a prostate cancer cohort identifies PCAT-1, an unannotated lincRNA implicated in disease progression. Nat Biotechnol 29 742-749. [PubMed] 